\title{
GRAND DESIGN PERENCANAAN PEMBANGUNAN EKONOMI BERBASIS EKONOMI KERAKYATAN DALAM UPAYA MENCAPAI PEMBANGUNAN BERKELANJUTAN DI KABUPATEN MALANG
}

\author{
Ferry Prasetyia \\ Farah Wulandari P \\ Fakultas Ekonomi Universitas Brawijaya
}

\begin{abstract}
The objective of this research is to analyse the possibility of community economy based (ekonomi kerakyatan) implementation in Malang district in order to achieve sustainable economic development. This reseach state that there are four stages in community economy based design: first, mapping the leading economic sectors in Malang District. Second, mapping of socio-political conditions surrounding the community. Third, identify the existing institutional order. Fourth, designing an appropriate form of partnership in order to accommodate the common good of the government, private sector, and society.
\end{abstract}

Keywords: community economy based, partnership, Malang district.

\section{A. LATAR BELAKANG}

Pencapaian pembangunan di berbagai tingkatan pemerintahan baik nasional maupun regional sangat bergantung kepada sinergitas peran pemerintah dan masyarakatnya. Sinergi yang diperlukan pemerintah dan masyarakat dalam hal pembagian peran dan kerja dalam merencanakan dan melaksanakan proses pembangunan. Keberhasilan pembangunan tidak akan tercapai secara optimal jika pemerintah tidak melibatkan peran masyarakat di dalam proses perencanaannya. Produkproduk pembangunan dapat menjadi produk tanpa makna bagi masyarakatnya, produk-produk yang manfaatnya tidak dapat mereka rasakan. Demikian pula sebaliknya, tanpa peran yang optimal dari pemerintah, pembangunan akan berjalan secara tidak teratur dan tidak terarah, yang akhirnya akan menimbulkan permasalahan baru.

Selain memerlukan keterlibatan masyarakat (partisipasi), pembangunan juga membutuhkan strategi yang tepat agar dapat lebih efisien dari segi pembiayaan dan efektif terhadap hasilnya. Partisipasi masyarakat justru adalah faktor paling determinan bagi keberhasilan pembangunan sebab mereka menduduki peran ganda, yaitu sebagai subyek pelaksanaan pembangunan dan sekaligus obyek terhadap hasil pembangunan. Oleh karena peran yang sentral dari masyarakat tersebut, maka dalam hal pembangunan khususnya pembangunan ekonomi sudah seharusnya pemerintah mereorientasikan kebijakan ekonominya berpihak pada rakyat atau dengan kata lain menggunakan sistem ekonomi kerakyatan. Diharapkan dengan berbasis pada ekonomi kerkayatan, kesenjangan pendapatan antara masyarakat dapat diminimalisir.

Malang sebagai salah satu kabupaten di Jawa Timur mengalami dualisme ekonomi dalam pembangunannya yang telah mengakibatkan kesenjangan pendapatan di masyarakat. Di sisi lain, relatif besarnya konstribusi baik dari sisi penyerapan tenaga kerja maupun investasi pada sektor ekonomi yang berbasis kerakyatan sudah seharusnya perencanaan pembangunan ekonomi di kabupaten malang berorientasi pada ekonomi kerakyatan. Disinilah pentingnya dilakukan penelitian 


\section{Grand Desain Perencanaan Pembangunan \\ Prasetyia dan Wulandari}

mengenai desain perencanaan pembangunan ekonomi berbasis ekonomi kerakyatan dalam upaya meningkatkan keberlanjutan ekonomi di Kabupaten Malang.

\section{B. KAJIAN TEORITIS}

\section{Sustainable Livelihood Approach dalam Pembangunan Ekonomi}

Pembangunan pertanian-pedesaan yang dipandu oleh ideologi sustainability memberikan platform yang jelas pada mekanisme-mekanisme penguatan kedaulatan civil society dan lokalitas untuk mengelola sepenuhnya sumberdaya alam dengan kearifan lokal yang dimiliki sesuai dengan etika ekosentrisme. Kesejahteraan sosial-ekonomi yang diperjuangkan dalam konsep sustainable development ideology adalah apa yang dikenal kemudian dengan sustainable livelihood system. Sebuah derajat kesejahteraan sosial- ekonomi, yang tidak hanya berorientasikan pada akumulasi kapital sesaat (sebagaimana dikenal oleh ideologi developmentalisme-modernisme-kapitalisme), namun lebih mementingkan pemenuhan kebutuhan generasi mendatang agar mereka minimal dapat menikmati kehidupan yang sama kuantitas dan kualitasnya dengan apa yang dinikmati oleh generasi masa kini, sperti terlihat pada gambar berikut.

Konsep ini sesungguhnya dikembangkan pertama kali di Inggris pada akhir dekade 1990an, namun didisain sedemikian rupa sehingga sangat relevan untuk kawasan sedang berkembang. Pendekatan pembangunan ala sustainable livelihood system adalah pendekatan pembangunan kontemporer (konsep pembangunan dekade 1990an) yang berusaha mengoreksi pendekatan pembangunan ala modernisasi yang dikenal sangat tidak akrab terhadap lingkungan. Pendekatan sistem nafkah berkelanjutan berusaha mencapai derajat pemenuhan kebutuhan sosial, ekonomi, dan ekologi secara adil dan seimbang. Pencapaian derajat kesejahteraan sosial didekati melalui kombinasi aktivitas dan utilisasi modal-modal yang ada dalam tata sistem-kehidupan. Sejumlah prinsip penting yang diperlukan untuk memahami konsep pengembangan komunitas berpendekatan sustainable livelihood mechanism, (Dharmawan, 2006) adalah:

- Landasan etika pembangunan adalah ekosentrisme, yaitu menghargai kesejajaran antara kepentingan manusia dan alam secara seimbang. Artinya, manusia dan alam hidup seiring sejalan dan memiliki hak serta kewajiban yang sama. Etika ini menghindari perilaku eksploitatif terhadap alam yang berlebihan demi pencapaian derajat kesejahteraan manusia.

- Ideologi environmentalisme dan eco-modernisme melandasi gerakan sosial masyarakat dalam berperilaku dan menyikapi pelestarian lingkungan. Ideologi ini tetap menempatkan pencapaian kehidupan manusia yang sejahtera, dalam waktu yang bersamaan tetap memandang penting pula untuk mengupayakan penyelamatan dan kelestarian sumberdaya alam dan lingkungan demi kehidupan manusia dan alam itu sendiri.

- Mengubah persepsi tentang pembangunan dari ciri eksploitatif ke ciri kearifan terhadap alam.

- Konsep rural sustainable development selalu mengintegrasikan kepentingan alam dan manusia dalam satu kesatuan paket-kepentingan yang diperjuangkan secara bersama-sama.

- Pendekatan participatory sustainable community empowerment yang menyertai prosesproses pengambilan keputusan, mengindikasikan adanya komitmen yang kuat atas pencapaian cita-cita keadilan lingkungan.

\section{Ruang Lingkup Perencanaan Pembangunan}

Perencanaan yang disusun oleh pemerintah terbagi atas lingkup perencanaan nasional dan lingkup perencanaan daerah. Ruang lingkup perencanaan nasional terdiri atas: Rencana Pembangunan Jangka Panjang Nasional, Rencana Pembangunan Jangka Menengah Nasional, Rencana Strategis Kementerian/Lembaga, Rencana Kerja Pemerintah, dan Rencana Kerja Kementerian/Lembaga. Sedangkan ruang lingkup perencanaan daerah terdiri atas: Rencana Pembangunan Jangka Panjang Daerah, Rencana Pembangunan Jangka Menengah Daerah, Rencana 
Strategis Satuan Kerja Perangkat Daerah, Rencana Kerja Pemerintah Daerah, dan Rencana Kerja Satuan Kerja Perangkat Daerah.

Sedangkan alur perencanaan dan penganggaran di tingkat pemerintah pusat dan pemerintah daerah adalah sebagai berikut:

Tahapan - tahapan perencanaan terdiri dari:

(1) Penyusunan Rencana

- Rancangan Rencana Pembangunan Nasional / Daerah

- Rancangan Rencana Kerja Dep / Lembaga SKPD

- Musyawarah Perencanaan Pembangunan

- Rancangan Akhir Rencana Pembangunan

(2) Penetapan Rencana (RPJP Nasional ditetapkan dengan Undang - Undang, sedangkan RPJP Daerah ditetapkan melalui Peraturan Daerah).

(3) Penetapan Rencana

- RPJP Nasional dengan Undang - Undang dan RPJP Daerah dengan Peraturan Daerah.

- RPJM dengan Peraturan Presiden / Kepala Daerah

- RKP / RKPD dengan Peraturan Presiden / Kepala Daerah

Proses penyusunan dan penetapan perencanaan jangka panjang melalui : (1) Rancangan Rencana, dimana proses teknokratik dilakukan oleh Bappenas/Bappeda (Bappeprop/ Bappekab/ Bappeko); (2) Musrenbang (Musyawarah perencanaan pembangunan) dengan bahan Rancangan Rencana yang melibatkan Masyarakat. Yang dimaksud dengan "masyarakat" adalah orang perseorangan, kelompok orang termasuk masyarakat hukum adat atau badan hukum yang berkepentingan dengan kegiatan dan hasil pembangunan baik sebagai penanggung biaya, pelaku, penerima manfaat maupun penanggung risiko. (3) Penyusunan Rancangan Akhir; (4) Pengendalian Pelaksanaan Rencana dan (5) Evaluasi Kinerja.

Pembangunan ekonomi yang efisien membutuhkan perencanaan yang teliti mengenai penggunaan sumber daya public serta peran sector swasta-petani, pengusaha kecil, koperasi, pengusaha besar dan organisasi-organisasi sosial. Melalui perncanaan pembangunan ekonomi daerah, suatu daerah dilihat secara keseluruhan sebagai suatu unit ekonomi (economy entity) yang didalamnya terdapat berbagai unsur yang terkait satu sama lain.

\section{Konsep Ekonomi Kerakyatan}

Ekonomi kerakyatan merupakan gagasan tentang cara, sifat, dan tujuan pembangunan dengan sasaran utama perbaikan nasib rakyat yang pada umumnya bermukim di pedesaan (Sumawinata, 2004). Bung Hatta sebagai salah satu pelopor ekonomi kerakyatan menekankan pada ekonomi kaum pribumi atau ekonomi penduduk asli. Hal ini disebabkan oleh kesadaran Bung Hatta bahwa perbaikan kondisi ekonomi rakyat tidak mungkin hanya disandarkan pada proklamasi kemerdekaan. Perjuangan untuk memperbaiki kondisi ekonomi rakyat harus terus dilanjutkan dengan mengubah struktur ekonomi Indoncsia dari sebuah perekonomian yang berwatak kolonial menjadi sebuah perekonomian nasional. Sebagaimana dikemukakan Bung Karno, yang dimaksud dengan ekonomi nasional adalah sebuah perekonomian yang ditandai oleh meningkatnya peran serta rakyat banyak dalam penguasaan modal atau faktor-faktor produksi di tanah air.

Jika dilihat dari segi konstituennya, konstituen utama ekonomi kerakyatan adalah kelompok masyarakat yang terpinggirkan dalam sistem ekonomi kapitalis neoliberal. Dalam garis besarnya mereka terdiri dari kaum buruh, kaum tani, kaum nelayan, pegawai negeri golongan bawah, usaha kecil-menengah, dan kaum miskin kota. Di luar kelima kelompok besar tersebut tentu terdapat berbagai kelompok masyarakat lainnya yang dapat pula digolongkan sebagai kelompok terpinggirkan (kaum mustad'afin) dalam sistem ekonomi kapitalis neoliberal.

Disisi lain, jika dilihat dari musuh strategisnya, musuh utama gerakan ekonomi kerakyatan terdiri dari para penguasa negara-negara industri pemberi ulang, perusahaan-perusahaan multinasional dan transnasional (MNC dan IC), lembaga-lembaga keuangan dan perdagangan mulitateral yang menjadi agen utama penyebarluasan kapitalisme neoliberal, para penguasa negara 


\section{Grand Desain Perencanaan Pembangunan}

Prasetyia dan Wulandari

yang menjadi kaki tangan kepentingan para pemodal besar, dan para pemodal besar domestik yang menghalang-halangi upaya perwujudan sistem ekonomi kerakyatan.

Sistem ekonomi kerakyatan, sebagaimana dikemukakan dalam Pasal 33 UUD 1945, adalah sebuah sistem perekonomian yang ditujukan untuk mewujudkan kedaulatan rakyat dalam bidang ekonomi. Tiga prinsip dasar ekonomi kerakyatan adalah sebagai berikut: (1) perekonomian disusun sebagai usaha bersama berdasar atas azas kekeluargaan; (2) cabang-cabang produksi yang penting bagi negara dan yang menguasai hajat hidup orang banyak dikuasai oleh negara; dan (3) bumi, air, dan segala kekayaan yang terkandung didalamnya dikuasai oleh negara dan dipergunakan bagi sebesar-besarnya kemakmuran rakyat. Berdasarkan ketiga prinsip tersebut dapat disaksikan betapa sangat besarnya peran negara dalam sistem ekonomi kerakyatan. Sebagaimana dilengkapi oleh Pasal 27 ayat 2 dan Pasal 34, peran negara dalam sistem ekonomi kerakyatan antara lain meliputi lima hal sebagai berikut: (1) mengembangkan koperasi (2) mengembangkan BUMN; (3) memastikan pemanfaatan bumi, air, dan segala kekayaan yang terkandung didalamnya bagi sebesarbesarnya kemakmuran rakyat; (4) memenuhi hak setiap warga negara untuk mendapatkan pekerjaan dan penghidupan yang layak; dan (5) memelihara fakir miskin dan anak terlantar.

\section{METODE PENELITIAN DAN ANALISIS DATA}

\section{Ruang Lingkup Penelitian}

Penelitian ini melingkupi dua hal yaitu ruang lingkup wilayah dan ruang lingkup materi. Ruang lingkup wilayah adalah pemerintah daerah kabupaten Malang serta instansi pendudukung lainnya di lingkungan Pemerintah Daerah Kabupaten Malang Jawa Timur.

Sedangkan ruang lingkup kajian materi meliputi: analisis ekonomi makro pada kabupaten Malang, dan teori serta kajian tentang perencanaan pembangunan ekonomi berbasis ekonomi kerakyatan. Selain itu juga, kegiatan ini akan membahas tentang permasalahan pembangunan ekonomi di Kabupaten Malang.

\section{Jenis dan Sumber Data}

Jenis data yang digunakan dalam penelitian ini adalah data sekunder dan data primer. Data sekunder yaitu data yang diperoleh secara tidak langsung dari objek penelitian. Data sekunder merupakan data yang tidak diperoleh dari sumbernya langsung, melainkan sudah dikumpulkan oleh pihak lain. Metode pengumpulan data dilakukan dengan teknik dokumentasi, yaitu pengumpulan data baku yang diperoleh pada Instansi atau Organisasi yang ada, baik pemerintah maupun swasta (Muslimin, $2002: 23$ ). Sumber data sekunder berasal dari beberapa instansi yang berwenang dalam pengeluaran data yaitu, APBN, APBD, badan perencanaan propinsi, kabupaten, Badan Pusat Statistik dan intansi-intansi terkait serta berbagai hasil penelitian yang berkaitan dengan kajian ini.

Sedangkan data primer diperoleh langsung melalui depth interview atau wawancara secara mendalam oleh peneliti. Dalam melakukan wawancara tersebut peneliti akan menggunakan pedoman interview yang telah disusun sebelumnya sehingga akan menghasilkan interview yang terarah sesuai dengan tujuan penelitian.

\section{Metode Analisis}

Dalam upaya mendesain perencanaan pembangunan ekonomi berbasis ekonomi kerakyatan dalam upaya mencapai pembangunan berkelanjutan, peneliti akan menggunakan metode penelitian eksploratif. Jenis penelitian ini berusaha mencari ide-ide atau hubungan-hubungan yang baru. Metode ini sangat fleksibel dalam pencarian gagasan dan ide serta petunjuk mengenai kondisi dan situasi yang berkaitan dengan permasalahan yang dikaji sehingga dapat memformulasikan kebijakan atau strategi yang tepat. 


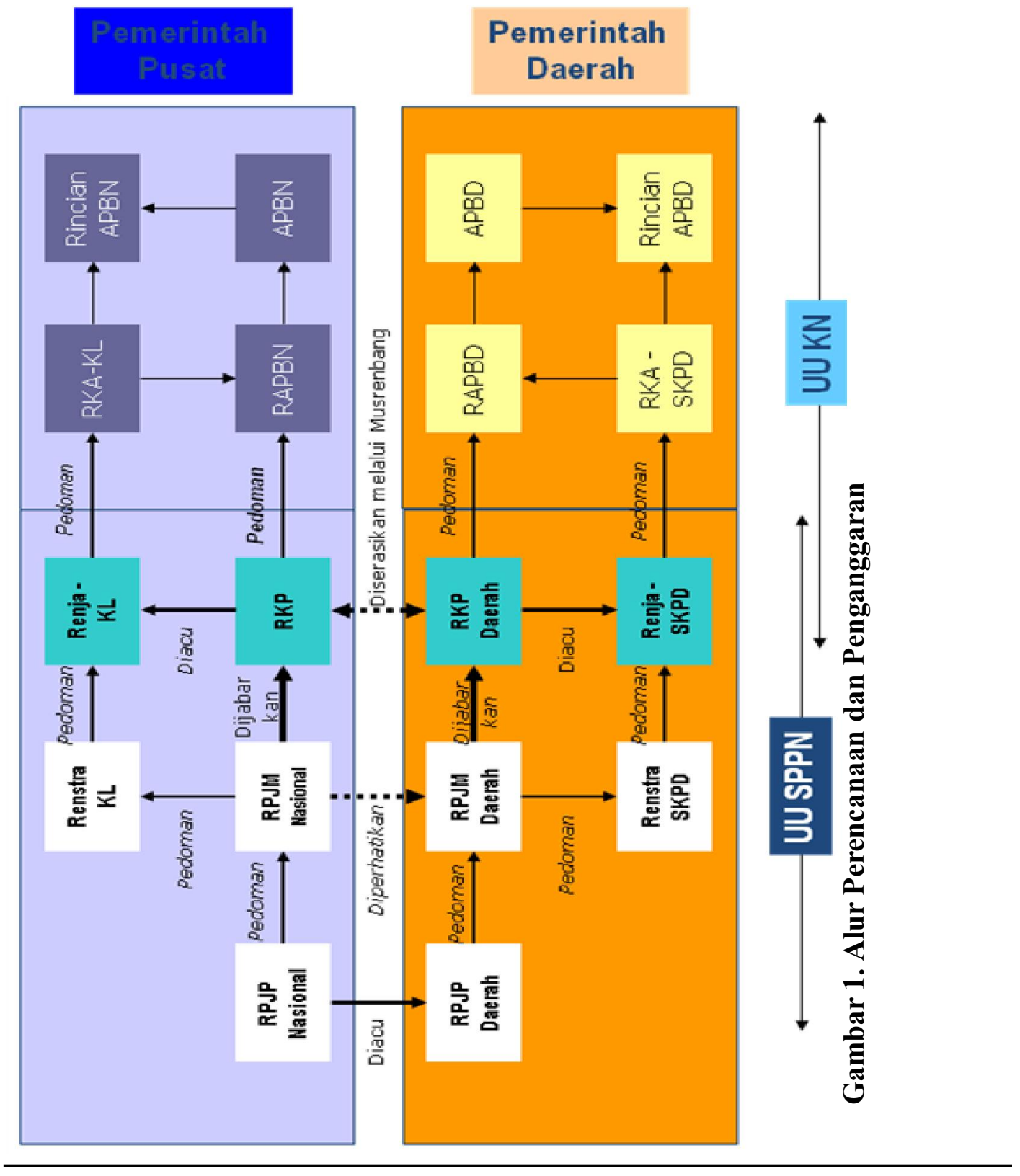




\section{Grand Desain Perencanaan Pembangunan \\ Prasetyia dan Wulandari}

Dengan metode penelitian ini, peneliti akan menggali permasalahan yang berkaitan dengan permasalahan pembangunan ekonomi di Kabupaten Malang Jawa Timur. Langkah pertama yang perlu dilakukan adalah mengumpulkan semua dokumen yang berkaitan dengan pembangunan ekonomi di Jawa Timur termasuk aspek keberhasilan dan kegagalannya. Selanjutnya mengidentifikasi permasalahan mulai dari gejala sampai masalah yang mendasar. Setelah proses identifikasi selanjutnya peneliti akan mengklasifikasikan masalah dan mendesain kebijakan perencanaan pembangunan ekonomi yang tepat yang diarahkan pada perencanaan pembangunan ekonomi berbasis kerakyatan. Selain itu, peneliti akan melakukan interview secara mendalam kepada setiap unit yang berkaitan dengan penelitian ini.

\section{HASIL DAN PEMBAHASAN}

\section{Kondisi Objektif Kabupaten Malang}

Berdasarkan hasil pembangunan Kabupaten Malang dari tahun 2006 sampai tahun 2008 menunjukan bahwa perkembangan pembangunan yang relatif menurun. Hal ini diindikasikan oleh beberapa hal seperti meningkatnya tingkat inflasi yang diiringi oleh penurunan pertumbuhan ekonomi pada thaun 2008. Selain itu juga terjadi peningkatan jumlah rumah tangga miskin dan stagnannya angka Indeks Pembangunan Manusia (IPM) (Tabel 1).

Meskipun faktor eksternal seperti krisis keuangan global lebih dominan dalam mempengaruhi penurunan kinerja pembangunan Kabupaten Malang pada tahun 2008, namun faktor fundamental ekonomi juga memegang peranan penting dalam menahan gejolak eksternal. Seperti telah disebutkan sebelumnya, kekuatan fundamental ekonomi salah satunya sangat ditentukan oleh kebijakan perencanaan. Sehingga dari kondisi tersebut kebijakan perencanaan pembangunan perlu dikaji ulang. Adanya pengkajian ulang diharapkan dapat memperkuat sendi-sendi perekonomian Kabupaten Malang. Oleh karena itu, perencanaan ekonomi berbasis kerkayatan bisa menjadi alternatif sehingga perlu dikaji dan diimplementasikan.

Selain dalam upaya memperkuat sendi-sendi perkenomian di Kabupaten Malang, penguatan ekonomi kerakyatan merupakan pengejawantahan amanat konstitusi/UUD 1945, diantaranya adalah: (1) perwujudan tata ekonomi yang disusun sebagai usaha bersama yang berasaskan kekeluargaan yang menjamin keadilan dan kemakmuran bagi seluruh rakyat Indonesia (pasal 33 ayat 1), (2) perwujudan konsep Trisakti (berdikari di bidang ekonomi, berdaulat di bidang politik, dan berkepribadian di bidang kebudayaan), (3) perwujudan cabang-cabang produksi yang penting bagi negara dan yang menguasai hajat hidup rakyat banyak dikuasai negara (pasal 33 ayat 2), dan (4) perwujudan amanat bahwa tiap-tiap warga negara berhak atas pekerjaan dan penghidupan yang layak (pasal 27 ayat 2). Adapun tujuan khusus yang akan dicapai adalah untuk:

1 Membangun Indonesia yang berdikari secara ekonomi, berdaulat secara politik, dan berkepribadian yang berkebudayaan

2 Mendorong pertumbuhan ekonomi yang berkesinambungan

3 Mendorong pemerataan pendapatan rakyat

4 Meningkatkan efisiensi perekonomian secara nasional

Dari berbagai hal diatas dapat dikemukakan bahwa landasan atau prinsip ekonomi kerakyatan bertumpu pada kekuatan domestik dan kemitraan antara pemerintah pusat maupun daerah dengan swasta dan masyarakat (public private partnership) untuk mencapai taraf kesejahteraan bersama. Sehingga desain perencanaan berbasis ekonomi kerkayatan sesuai dengan pasal 33 UUD 1945 lebih berbentuk usaha bersama dengan pemerintah sebagai regulator dan swasta serta masyarakat sebagai pelaku ekonomi. Selain itu, pemerintah dapat bersinergi dengan pihak swasta dan masyarakat dalam melakukan aktivitas ekonomi. Berdasarkan hal tersebut dapat dikatakan bahwa desain perencanaan pembangunan ekonomi berbasis ekonomi kerakyatan mensinergikan seluruh komponen masyarakat dan pemerintah untuk mencapai kesejahteraan bersama. 
Tabel 1. Ringkasan Hasil Pembangunan Kabupaten Malang

\begin{tabular}{clrrr}
\hline No & \multicolumn{1}{c}{ INDIKATOR } & \multicolumn{1}{c}{$\mathbf{2 0 0 6}$} & \multicolumn{1}{c}{$\mathbf{2 0 0 7}$} & \multicolumn{1}{c}{$\mathbf{2 0 0 8}$} \\
\hline 1. & Indeks Pembangunan Manusia (IPM) & $66,93 \%$ & $67,75 \%$ & $67.75 \%$ \\
& - Indeks Angka Harapan Hidup & & & \\
& - Indeks Pendidikan & $69,30 \%$ & $70,50 \%$ & $70.50 \%$ \\
& - Indeks Daya Beli & $73,72 \%$ & $74,87 \%$ & $74.84 \%$ \\
& & $57,76 \%$ & $57,89 \%$ & $57.84 \%$ \\
2. & PDRB - ADHB (Rp. Juta) & $19.030 .257,31$ & $21.595 .800,21$ & $24,478,845.90$ \\
3. & PDRB - ADHK (Rp. Juta) & $11.617 .936,65$ & $12.325 .207,43$ & $13,034,722.46$ \\
4. & Pertumbuhan Ekonomi ADHK & $5,74 \%$ & $6,09 \%$ & $5.76 \%$ \\
5. & Infla si & $11,76 \%$ & $6,97 \%$ & $7,61 \%$ \\
6. & Pendapatan Perkapita ADHB & $7.093 .700,00,-$ & $8.215 .877,50,-$ & $9,640,000.00$ \\
7. & Pendapatan Perkapita ADHK & $4.511 .378,00,-$ & $4.688 .985,52,-$ & $4,906,153.17$ \\
8. & Rumah Tangga Miskin & $163.910 \mathrm{KK}$ & $162.341 \mathrm{KK}$ & $163,911 \mathrm{KK}$ \\
\hline
\end{tabular}

Sumber: BPS (2009)

\section{Desain Perencanaan Pembangunan Ekonomi Kerakyatan di Kabupaten Malang}

Pembangunan ekonomi pada umumnya didefinisikan sebagai suatu proses yang menyebabkan kenaikan pendapatan riil per kapita penduduk suatu negara/wilayah regional dalam jangka panjang yang disertai oleh perbaikan sistem kelembagaan. Dalam rangka membangun perekonomian berbagai kebijakan publik telah disusun dan dilaksanakan oleh pemerintah untuk meningkatkan kesejahteraan penduduknya, mengembangkan struktur perekonomian dan memperbaiki sistem kelembagaan baik dari aspek bidang organisasi maupun regulasi. Di era otonomi daerah sekarang ini, pemerintah daerah memiliki keleluasaan untuk menyelenggarakan kewenangan pemerintahan di bidang tertentu yang secara nyata ada dan diperlukan serta tumbuh, hidup dan berkembang di daerah. Dengan demikian, pemerintah daerah memiliki keleluasaan untuk mengembangkan potensi daerah dan mengelola sumber kekayaan alamnya, menentukan prioritas dan arah program pembangunan ekonomi daerah. Untuk mencapai tujuan diatas maka diperlukan perencanaan yang teliti dan evaluasi terhadap hasil-hasil pembangunan yang telah dicapai.

Perencanaan di bidang ekonomi di kabupaten Malang perlu memperhatikan hal-hal berikut: i). Upaya meningkatkan pembangunan ekonomi yang signifikan dengan pendapatan masyarakat secara mantap dan berkesinambungan; ii). Upaya mencapai pertumbuhan ekonomi yang ideal sehingga pemerataan pendapatan dapat dinikmati secara merata oleh masyarakat dengan penyerapan kesempatan kerja secara maksimal. Oleh karena itu, evaluasi terhadap pelaksanaan pembangunan ekonomi di suatu daerah tidak terlepas dari kedua masalah tersebut.

Sebelum mendeskripsikan desain perencanaan pembangunan, terlebih dahulu perlu dipahami sasaran pokok dari konsep ekonomi kerakyatan seperti yang telah dijelaskan sebelumnya. Bila tujuan utama ekonomi kerakyatan tersebut dijabarkan lebih lanjut, maka sasaran pokok ekonomi kerakyatan dapat dilihat dari dua dimensi yaitu dimensi ekonomi dan sosial. Penjelasan lebih detail mengenai sasaran pokok ekonomi kerakyatan dapat diilustrasikan pada gambar 2 .

Sesuai dengan sasaran pokok ekonomi kerakyatan diatas maka desain konsep perencanaan pembangunan ekonomi berbasis kerakyatan khususnya pada lingkup Kabupaten Malang dapat dirumuskan. Perumusan konsep tersebut setidaknya harus memuat beberapa pertanyaan fundamental yaitu, pertama, orientasi dan arah pembangunan; kedua, apakah dan siapakah yang menjadi pendorong dan pelaksana pembangunan tersebut; dan ketiga, dalam suasana sosial politik yang bagaimana pembangunan itu diadakan.

Menjawab pertanyaan tersebut dengan menyesuaikannya pada kondisi Kabupaten Malang, maka dapat diarahkan pada: pertama, arah pembangunan untuk menyerap tenaga kerja lokal dan memberi stimulus pada rakyat dengan memperhatikan keunggulan dan daya saing yang dimiliki. Kedua, pelakunya diorientasikan pada masyarakat di Kabupaten Malang sesuai dengan bidang usaha yang dimiliki dari berbagai sektor. Ketiga, bentuk kemitraan berupa sosial kekerabatan untuk daerah yang karakter masyarakatnya masih tradisional, di mana kondisi sosial politik yang dihadapi masih 
sederhana. Sedangkan di daerah yang masyarakatnya sudah maju berbentuk sosial benefisial di mana kondisi sosial politiknya sudah terdapat muatan-muatan untuk mencari keuntungan.

Berdasarkan beberapa hal diatas, langkah identifikasi desain dapat dimulai dari tahapan berikut (gambar 3): pertama, pemetaan sektor-sektor ekonomi unggulan di Kabupaten Malang. Kedua, pemetaan kondisi sosial politik yang melingkupi masyarakat. Ketiga, mengidentifikasi bentuk pranata kelembagaan yang ada. Keempat, mendesain bentuk kemitraan yang sesuai agar dapat mengakomodasi kepentingan bersama baik dari sisi pemerintah, swasta, dan masyarakat secara luas.

Tahap pertama dari desain perencanaan pembangunan ekonomi berbasis kerakyatan adalah pemetaan potensi dan sektor unggulan di Kabupaten Malang. Pemetaan tersebut dapat memberikan suatu gambaran menyeluruh mengenai sektor-sektor usaha yang memiliki konstribusi dan berpotensi untuk meningkatkan kesejahteraan masyarakat. Identifikasi terhadap sektor unggulan dapat dilihat dari kontribusi sektor usaha terhadap pendapatan domestik regional bruto (tabel 2).

Berdasarkan Tabel 2, dapat dilihat bahwa konstribusi sektoral di Kabupaten Malang pada tahun 2008 berdasarkan harga konstan didominasi oleh empat sektor utama yakni sektor pertanian (31\%); perdagangan, hotel, dan restoran (24\%); industri pengolahan (18\%); dan jasa-jasa (13\%). Sementara sektor-sektor lainnya secara keseluruhan menyumbang 17\% kepada pertumbuhan ekonomi Kabupaten Malang. Berdasarkan konstribusi sektoral tersebut sudah seharusnya perhatian pemerintah Kabupaten Malang berfokus dan diprioritaskan pada sektor-sektor tersebut. meskipun demikian, sektor-sektor lainnya juga harus mendapat perhatian dikarenakan sektor tersebut bisa menjadi faktor pendukung bagi peningkatan di sektor-sektor prioritas.

Dalam upaya mendesain perencanaan pembangunan yang berkaitan dengan pemetaan potensi dan unggulan, sangat diperlukan pemahaman tentang permasalahan yang terjadi seperti di sektor pertanian, sektor pedagangan, sektor jasa-jasa dan sektor industri. Permasalahan utama dalam sektor pertanian adalah ketersediaan lahan. Meningkatnya jumlah petani yang tidak mempunyai lahan garapan yang cukup dalam 3 dekade terakhir, dan hilangnya spesifikasi pemilikan komunal atas sumber daya alam, merupakan ancaman serius dalam membangun ekonomi kerakyatan.

Tabel 2. Konstribusi Sektoral terhadap Pertumbuhan Ekonomi Kabupaten Malang tahun 2008 Berdasar Harga Berlaku, dan Konstan tahun 2000 (dalam Persen)

\begin{tabular}{l|l|r|r}
\hline No & \multicolumn{1}{|c|}{ S e k t o r } & Berlaku & Konst an \\
\hline 1 & Pertanian & 28.61 & 30.47 \\
\hline 2 & Perta mbangan dan Penggalian & 2.25 & 2.69 \\
\hline 3 & Industri Pengolahan & 20.12 & 18.37 \\
\hline 4 & Listrik Gas dan Air & 1.91 & 1.55 \\
\hline 5 & Bangunan & 1.82 & 1.68 \\
\hline 6 & Perdagangan, Hotel, dan Restoran & 23.94 & 23.97 \\
\hline 7 & Angkutan dan Komunikas i & 4.97 & 4.38 \\
\hline 8 & Keuangan, Persewa an\& Jas a Perusahaan & 3.78 & 3.85 \\
\hline 9 & Jasa-jasa & 12.60 & 13.04 \\
\hline & Pert umbuhan Ekonomi & $\mathbf{5 , 7 6}$ & $\mathbf{5 , 7 6}$ \\
\hline
\end{tabular}

Sumber: BPS (2009)

Data empiris menunjukan bahwa kepemilikan petani rakyat hanya rata-rata 0,4 hektar area, hal tersebut tentu saja menggambarkan kondisi yang sangat kurang dan dapat menyebabkan inefisiensi. Selain itu, karena lahan garapan sedikit menyebabkan pengadaan sarana produksi pertanian juga dengan jumlah sedikit. implikasinya adalah akan meningkatkan harga perunit sarana 


\section{Journal of Indonesian Applied Economics}

Vol. 3 No. 1 Mei 2009, 48-58

produksi, dan pada akhirnya biaya produksi per unit produk menjadi tinggi. Dengan skala produksi yang kecil dan keuntungan kecil, akan menjadi kendala untuk terjadinya akumulasi kapital di setiap unit produksi. Sehingga dapat menyebabkan pembentukan capital (capital formation) atau investasi baru akan sangat sulit terwujud baik dalam hal intensifikasi maupun ekstensifikasi sektor pertanian.

Dengan skala usaha kecil-kecil dengan jumlah jutaan dan tidak ada keterkiatan antara satu dengan yang lain, menyebabkan posisi tawar petani baik di pasar input maupun di pasar output, sangat lemah. Di pasar input petani dihadapkan pada persoalan monopolist, sedang di pasar output dihadapkan dengan masalah monopsoni. Oleh sebab itu, jalan keluar yang relatif baik adalah melalui merger antarunit usaha pertanian atau coorporate farming. Melalui coorporate farming (CF), produksi pertanian dilakukan melalui unit-unit perusahaan pertanian yang saham seluruhnya dimiliki oleh petani yang bersangkutan. Model CF tidak saja diterapkan untuk pertanian tanaman pangan, tetapi juga untuk perkebunan.

Sedangkan disektor perdagangan permasalahan utama yang menghadang adalah struktur usaha lebih bersifat terintegrasi dan monopoli. Seperti diketahui bahwa di sektor perdagangan terdiri dari unsur distributor, retail besar, dan retail kecil. Perusahaan distributor pada umumnya dimiliki atau merupakan anak perusahaan dari produsen atau dimiliki oleh perusahaan terbatas yang pemilik bukan produsen tetapi sebagian sahamnya dimiliki oleh produsen. Pemilikan saham di distributor dan retail besar, pada umumnya hanya oleh sebagian kecil orang. Dalam rangka penguatan ekonomi kerayatan, struktur pemilikan saham di distributor dan retail besar, perlu dilakukan peninjauan kembali. Intinya adalah, sebanyak-banyaknya warga negara harus memiliki saham di sektor perdagangan. Bentuknya adalah, retail-retail kecil harus membentuk koperasi. Melalui koperasi ini, retail-retail kecil memiliki saham di retail besar dan di distributor.

Tahapan kedua dan ketiga dari desain perencanaan pembangunan ekonomi berbasis kerakyatan adalah pemetaan kondisi social dan politik; dan pranata kelembagaan. Kedua hal tersebut memiliki keterkaitan satu sama lain. Pemetaan yang berkaitan dengan kondisi social dan politik berhubungan dengan identifikasi terhadap hal-hal berikut:

1 Tingkat pendidikan dan kesehatan masyarakat

2 Hak kepemilikan unit produksi: privat, komunal/umum, negara, bebas

3 Struktur politik termasuk partai politik

4 Struktur sosial masyarakat: sosial kekerabatan, sosial benefisial

5 Sektor: primer, sekunder, tersier, pertanian, industri, dan lain-lain

6 Bentuk usaha: usaha keluarga, industri kreatif, industri rumah tangga, industri menengah

Sedangkan pranata kelembagaan berkaitan dengan aturan-aturan maupun norma yang berada di Kabupaten Malang. Aturan tersebut penting dalam upaya memberikan aturan yang jelas mana yang boleh atau tidak boleh dilakukan baik yang bersifat formal (hukum formal) maupun non formal (adat istiadat, norma agama). Selain itu, adanya pranata kelembagaan yang baik akan menciptakan kondusi yang efektif fan kondusif bagi jalannya pemerintahan dan perekonomian di Kabupaten Malang.

Tahapan terakhir dari desain ekonomi kerakyatan ditekankan pada sinergi antara pemerintah, swasta, dan masyarakat. Dalam posisi tersebut, pemerintah berkedudukan sebagai perumus kebijakan, palaku dan regulator agar swasta tetap bergerak pada rel yang digariskan yaitu untuk mencapai kesejahteraan masyarakat banyak. Swasta yang dapat berasal dari pemilik modal domestik maupun asing berkepentingan besar untuk mencapai keuntungan sebesar-besarnya atas investasi yang sudah dikeluarkannya. Oleh karena itu, peran pemerintah dapat bertindak sebagai regulator dan juga pelaku agar dapat mempengaruhi harga secara wajar baik melalui BUMN maupun BUMD. Selanjutnya, posisi masyarakat sebagai pemegang share terbesar dari pembangunan menjadi hal yang sangat penting khususnya dalam menggerakan pembangunan ekonomi. Oleh sebab itu, pemberian kesempatan yang luas dan bargaining position yang kuat dalam aktivitas ekonomi menjadi komponen penting bagi masyarakat. Hal tersebut bisa diwujudkan dalam bentuk paguyuban masyarakat, koperasi dan asosiasi lainnya. Disinilah perlunya sinergi yang kuat antara pihak 


\section{Grand Desain Perencanaan Pembangunan \\ Prasetyia dan Wulandari}

pemerintah, swasta dan Masyarakat dalam upaya menyeleraskan peran masing-masing dalam proses pembangunan.

Dari berbagai tahapan identifikasi perencanaan pembangunan ekonomi berbasis ekonomi kerakyatan, dapat dikatakan bahwa desain tersebut harus mengedepankan pencapaian kesejahteraan bagi semua kalangan, baik dari kalangan ekonomi lemah, menengah, sampai mapan. Dengan demikian, desain perencanaan benar-benar mempertimbangkan kondisi masyarakat sehingga kebijakan tidak berupa 'pemaksaan' melainkan berbentuk 'fasilitasi' dan pemberdayaan masyarakat. Sehingga, semua elemen masyarakat dapat diakomodasi kepentingannya sehingga desain ekonominya lebih masif dan menyeluruh.

\section{E. KESIMPULAN DAN REKOMENDASI}

\section{Kesimpulan}

Berdasarkan permasalahan dan hasil analisis, ada beberapa poin penting yang dapat disimpulkan yaitu:

1. Kabupaten Malang memiliki potensi unggulan baik dari sektor pertanian maupun industri dan jasa.

2. Perencanaan pembangunan di Kabupaten Malang selama ini, meskipun telah melibatkan unsur masyarakat seperti melalui musrenbangdes, tetapi sasaran akhir dari pembangunan belum menyentuh dan meningkatkan aspek kesejahteraan masyarakat secara signifikan.

3. Proses desain perencanaan ekonomi berbasis kerakyatan diawali dengan identifikasi potensi dan sektor unggulan yang ada di kabupaten Malang. Selanjutnya adalah pemetaan kondisi social politik, dan pranata kelembagaan yang ada. Terakhir adalah mensinergikan peran pemerintah, swasta dan masyarakat.

4. Desain perencanaan pembangunan ekonomi di Kabupaten Malang sesuai ekonomi kerakyatan diarahkan pada penyerapan tenaga kerja lokal dan memberi stimulus pada rakyat di Kabupaten Malang dengan memperhatikan keunggulan dan daya saing yang dimiliki. Selanjutnya, pelakunya diorientasikan pada masyarakat di Kabupaten Malang sesuai dengan bidang usaha yang dimiliki dari berbagai sektor. Terkahir, bentuk kemitraan antara pemerintah dengan swasta dan masyarakat diperlukan dalam mensinergikan berbagai aktivitas ekonomi dalam pencapaian kesejahteraan masyarakat.

\section{Rekomendasi}

Sesuai hasil analisis, beberapa saran dan rekomendasi baik bagi pemerintah maupun stakeholder yang berkepentingan adalah sebagai berikut:

1. Pemerintah Kabupaten Malang dengan berbagai keunggulan sumber daya alam dapat mendesain pembangunan yang berbasis pada ekonomi kerakyatan;

2. Masyarakat dan pihak swasta lebih berperan aktif dalam kegiatan pembangunan di Kabupaten Malang melalui aktivitas produktif dalam upaya meningkatkan kesejahteraan masyarakat secara umum.

3. Sinergi antara pemerintah dan masyarakat dibutuhkan dalam upaya menyukseskan pembangunan yang berkelanjutan.

\section{DAFTAR PUSTAKA}

Bafadal, Ibrahim. 2002. Teknik Analisa Data Penelitian Kualitatif. Dalam Metodologi Penelitian Kualitatif, Tinjauan Teoritis dan Praktis (Editor Masykuri Bakri), Cetakan Pertama, hal. 173186. Lembaga Penelitian Universitas Islam Malang dan Visipress, Malang. 
Baswir, Revrisond. 2009. Ekonomi Kerakyatan vs. Neoliberalisme. www.spi.or.id diakses 6 Desember 2009.

Baswir, Revrisond. Tanpa Tahun. Ekonomi Kerakyatan: Ekonomi Rakyat dan Koperasi Sebagai Sokoguru Perekonomian Nasional.

Berenger, Valeria \& Audrey Verdier Chauchane. 2007. Multidimensional Measures of Well-Being: Standard of Living and Quality of Life Across Countries. World Development. Vol. 35, No. 7 , pp. 1259-1276.

Biro Pusat Statistik (BPS). 2009. Malang dalam Angka tahun 2009.

Dharmawan, A. H. 2000. Poverty, Powerlessness, and Poor People Empowerment: A Conceptual Analysis with Special Reference to the Case of Indonesia. Paper presented in the Workshop on Rural Institutional Empowerment held in the Indonesian Consulate General of the Republic of Indonesia in Frankfurt am Main Germany, August $26^{\text {th }} 2000$.

Farrington, J. et. al. 1999. Sustainable Livelihoods in Practice : Early Applications of Concepts in Rural Areas'. ODI Natural Resources Perspectives. Number 42. June 1999. Overseas Development Institute. London.

Hutomo, Mardi Yatmo. 2008. Konsep Ekonomi Kerakyatan. www.bappenas.go.id/.../konsep-ekonomikerakyatan-oleh-mardi-yatmo-hutomo-/ _ diakses tanggal 01 desember 2009

Miles, B. Mathew dan Huberman, A. Michael. 1992. Analisa Data Kualitatif. UI-Press, Jakarta.

Sumawinata, Sarbini. 2004. Politik Ekonomi Kerakyatan. PT Gramedia Pustaka Utama. Jakarta. 